\title{
A Review on Environmental Radon and Its Potential Health Risk on Humans
}

\author{
Ojo T. $\mathbf{J}^{1^{*}}$ and Ajayi I. $\mathrm{R}^{2}$ \\ ${ }^{1}$ Dept. of Science Technology, Federal Polytechnic, P.M.B 5351, Ado-Ekiti, Nigeria \\ ${ }^{2}$ Dept. of Physics and Electronics, Adekunle Ajasin University, P.M.B 001, Akungba Akoko, Ondo State Nigeria
}

\begin{abstract}
Radon is a naturally occurring, odorless, colorless and radioactive inert gas produced by the breakdown of uranium in soil, rock, and water. Because radon is a gas, it can enter buildings through openings or cracks in the foundation. The radioactive radon gas itself decays into radioactive solids, called radon daughters. The radon daughters attach to dust particles in the air, and can be inhaled. The inhalation of radon daughters has been linked to lung cancer. As a result of this, radon has been identified as the second leading cause of lung cancer next to smoking in the United States and other parts of the world. "WHO has suggested that homeowners take action when radon levels exceed $2.7 \mathrm{pCi}$ il in order to save themselves from lung cancer that can be caused by radon and its daughters" This Paper presents a review on the production of radon, its mode of release into the home and environment, exposure route and potential health effects. It also highlights the need to conduct nationwide radon survey in order to generate detailed data bank on radon exposure.
\end{abstract}

\section{Introduction}

Attention to the problem of radon exposure and the associated health risks has been growing around the world. According to the assessments made by the United Nations Scientific Committee on the Effects of Atomic Radiation [1], radon in the natural environment constitutes about 53\% of the human exposure to natural radiation. In underground mining, mainly uranium mining, incidence of excess lung cancer has been observed in the United States (Colorado) the Czech Republic, and Canada (Ontario). This also has been the case among underground fluorspar miners and in iron ore miners in Sweden. Today, the scientific community agrees on the link between the incidence of excess lung cancer among underground miners and exposure to radon and its daughters. Current knowledge of potential health effects from radon exposure in dwellings, on the other hand, is rather limited. The relationship between the incidence of excess lung cancer among underground miners and exposure to radon cannot be sensibly used to understand potential health risks to the public. This is because the level of exposure in dwellings is much lower than in mines. There are opinions that the incidence of excess lung cancer among early uranium miners may be explained by synergistic effects of heavy smoking, ore dust, toxic fumes, etc. and extremely high radon exposures. The IAEA and the International Labour Office acknowledged the importance of controlling radon exposure in places other than mines. These places are varied in nature, such as waterworks, caves and closed-out mines open to visitors, underground stores and shopping centres, spas, kindergartens, schools, factories, shops, public buildings, residential buildings and offices. For this reason, the two organizations considered it necessary to prepare a joint Safety Report on radiation protection in places other than mines. Also in the late 1980s, the IAEA and Commission of the European Communities initiated a 5-year co-ordinated research programme (CRP) on radon in the human environment. More than 50 countries now have ongoing projects, an indication of the high level of interest in this subject.

\section{Risks Of Radon Exposure}

Principally, soil is the source of radon-222. It is the daughter product of radium-226. Thoron (radon220 ) is produced by the alpha decay of radon-224. Radon and thoron are noble gases which can migrate from the soil either by molecular diffusion or by convection and enter the atmosphere and water bodies. The distribution of radon in the air depends on meteorological conditions. Radon gas is ubiquitous - outdoors as well as indoors, the air that we inhale contains radon. Radon decays to a number of short lived decay products ('progeny') that are themselves radioactive. These may attach to available aerosol particles in the atmosphere, thereby forming what are termed 'attached' radon progeny. Those radon progenies that do not attach to aerosols remain in what is termed the 'unattached' state. If inhaled, both unattached and attached radon progenies may deposit in the lungs and irradiate lung tissue as they decay. In lung dosimetry models, in which deposition sites of radioactive material and locations of target cells are taken into account, the risk per unit of inhaled radioactive material is considered to be much greater for radioactive material in the unattached state than for radioactive material in the attached state [26]. While it is the radon progeny rather than radon gas itself that presents the greater risk, the word 'radon' is also used generally as a convenient shorthand for both the gas and its progeny. Radon has been recognized as a radiation hazard causing excess lung cancer among underground miners [27]. 
Consequently radon has been classified as a human carcinogen [27]. Since the 1970s, evidence has been increasing that radon can also represent a health hazard in non-mining environments [26, 27]. Since environmental radon on average accounts for about half of all human exposure to radiation from natural sources [1], increasing attention has been paid to exposure to radon and its associated health risks in both industrialized and developing countries.

\section{Genetic damage caused by radon}

The increased risk of lung cancer from radon primarily results from alpha particles emitted by the short lived radon daughters, which penetrates the cell nucleus. The passage of these energetic alpha particles may damage the DNA, the inherited compound that controls the structure and function of cells. The alpha particles initiate the DNA damage by breaking the electron bonds that hold molecules together. The DNA damage may occur directly by displacement of electrons from the DNA molecule, or indirectly by changing the structure of other molecules in the cell, which may then interact with the DNA. When one of these events occurs, a cell can be destroyed quickly or its growth or function may be altered, thus causing genomic changes typically in the form of point mutations and transformations. Fortunately cells have the ability to repair the damage done to DNA by radiation, chemicals, or physical trauma. The effectiveness of these cellular repair mechanisms depends on the kind of cell, the type and dose of radiation, the individual and other biological factors. [26]

\section{Health effects caused by reactive oxygen species resulting from radon exposure}

Radon exposure may also cause toxic health effects through production of oxygen radicals otherwise known as reactive oxygen species (ROS). ROS consists of chemically reactive super-oxide (pair of oxygen atoms) and hydrogen peroxide, the later being electrically charged. These intermediate molecules damage nucleotide bases and form DNA lesions as secondary by-products of formation [27]. Therefore, these molecules could be the source of damage within a cell that sparks the onset of cancer, since they can persist and continue to cause mutations in DNA. This negates the widely held assumption that alpha particles cause genetic changes only through direct traversals of cell nuclei. The interaction of alpha particles with the fluids that line the lungs damages the DNA of nearby cells. Exposure even to the lowest doses of alpha emission produces the very reactive chemicals within cells and their production increases with the alpha-particle dose. This confirms that radon is dangerous even at very low exposure levels i.e. no safe threshold. A study by Day (1999) provides clear evidence that a single alpha particle can induce mutations and chromosome aberrations in cells that received no direct radiation exposure to their DNA. These results indicate the need to re-assess the potential genotoxic effect of low dose radiation and suggest that the adoption of direct proportionality in radiation may significantly underestimate the risk of low-dose radiation. Radon gas is soluble in lipids and accumulates in lipid tissue throughout the body with the highest concentration in the brain, bone marrow, and nervous system. But none of its heavy metal daughters are soluble in the lipids and consequently, remain trapped in the brain and bones, where they continue to emit gamma radiation and alpha particles. This may result in development of leukemia, which is a cancer of the blood and other types of cancers. Some animals exposed to high concentrations of radon progeny display beside lung carcinoma other diseases such as emphysema, pulmonary fibrosis, and a shortened life span. Furthermore deposition of radon gas carried by aerosol particles on basal layers of the skin may result in development skin cancer. Nevertheless, the risk of other types cancer or diseases is much lower than that of lung cancer. ICRP estimated the cancer risk to other organs at about $2 \%$ of the lung cancer risk [27]

\section{Teratogenic effects caused by radon exposure}

Exposure to alpha particle during early stages of a fetus development may have profound effects on the health and survival of the fetus. This is because dissolved radon in the blood stream of the mother can pass through the placenta into the developing child. During the embryo phase of a fetus, formation of DNA lesions arising from deposition of radon progeny may result in death of the fetus. At such an early developmental stage, the presence of inheritable DNA lesions causes too much genomic instability and result in negative growth response of the fetus. On the other hand, if the developing child is in the fetal stages, a radon particle passing into the fetus would likely move to lipid portions of the unborn child, namely the brain and other organs. At this stage, exposure to alpha particle may not result in death of the fetus but results in severe inhibition in brain development leading to mental retardation. After birth, exposure follows the same pathways as for adults [26, 27].

\section{Radon In Dwellings}

In buildings with high radon levels, the main mechanism for the entry of radon is the pressure driven flow of gas from soil through cracks in the floor. This flow arises because buildings are normally at a slight under-pressure with respect to their surroundings. This under-pressure is a consequence of the air inside buildings being warmer than that outside, especially in temperate and cold regions, and also of the drawing 
effect of the wind blowing over chimneys and other openings. However, various other mechanisms can affect the concentrations of radon in dwellings depending on how such houses are built and ventilated, radon may accumulate in basements of dwellings. Radon can also seep into an indoor environment through cracks in construction joints, cracks in walls, gaps in suspended floors, gaps around service pipes, cavities inside walls, and the water supply. The concentration in one room of a building may be significantly different from the concentration in an adjoining room. Most building materials produce some radon but building materials of certain types can act as significant sources of indoor radon. Such building materials have a combination of elevated levels of ${ }^{226} \mathrm{Ra}$ and a high porosity that allows the radon gas to escape. Examples are light weight concrete made with alum shale, phosphogypsum and Italian tuff. Levels of radon can be high in groundwater, particularly in areas of granite rock. Radon levels may be high in workplaces such as laundries and restaurant kitchens as a result of the use of such water. Since many municipal water supplies are provided from surface reservoirs filled by rain catchment, radon levels in public water supplies are not normally high. In Germany some treatment and distribution stations for water supplies drawn from groundwater have been found to have radon concentrations in air of up to several hundred thousand $\mathrm{Bq} / \mathrm{m}^{3}$ [2]. Generally, the annual exposure time of workers in these workplaces is low, but several such water treatment plants are subject to monitoring. Some countries have issued recommendations on radon concentrations in drinking water [3]. Elevated levels of radon have been found in workplaces in various countries. A summary is given in Tables I and II. It can be seen that radon levels are rather variable. Some countries, but not all, have identified certain workplaces with radon concentrations exceeding $1000 \mathrm{~Bq} / \mathrm{m}^{3}$.

Table I. Radon Concentrations In Underground Places (Non-Mining)

\begin{tabular}{llc}
\hline Workplace type & Country/Radon concentration & Reference \\
\hline Tourist caves & Germany 400-11 180 & {$[4]$} \\
& Hungary 130-21 100 & {$[5]$} \\
& Ireland 260-19 060 & {$[6]$} \\
& Slovenia 20-10 000 & {$[7,8]$} \\
& USA 48-1 850 & {$[9,10]$} \\
Mines open to visitors & Germany 400-20 280 & {$[4]$} \\
Tunnels & Czech Republic 229-3 312 & {$[11]$} \\
& Finland 500-7 000 & {$[12]$} \\
Power stations & Norway 250 (mean) & {$[13]$} \\
Underground railways & Norway 20-4 000 & {$[13]$} \\
& Finland 45-200 (stations); & {$[12]$} \\
& 20-790 (workplaces) & {$[14]$} \\
\hline
\end{tabular}


Table II. Radon Concentrations In Above Ground Workplaces

\begin{tabular}{|c|c|c|c|c|}
\hline $\begin{array}{l}\text { Workplace } \\
\text { type }\end{array}$ & Location & $\begin{array}{l}\text { Number } \\
\text { surveyed }\end{array}$ & $\begin{array}{ll}\text { Radon } & \text { concentration } \\
\left(\mathrm{Bq} / \mathrm{m}^{3}\right) & \end{array}$ & Reference \\
\hline \multirow[t]{4}{*}{$\begin{array}{l}\text { Public } \\
\text { buildings }\end{array}$} & $\begin{array}{l}\text { Belgium } \\
\text { (Luxembourg } \\
\text { province) } \\
\end{array}$ & 36 & $\begin{array}{l}10 \%>200 \\
3 \%>400\end{array}$ & {$[15]$} \\
\hline & Finland & 155 & Mean 505, 37\%>300 & [16] \\
\hline & & 400 & Mean 284, 17\%>300 & [16] \\
\hline & USA & 3901 & $22 \%>150,0.2 \%>1000$ & [17] \\
\hline \multirow[t]{7}{*}{ Schools } & $\begin{array}{l}\text { Belgium } \\
\text { (Luxembourg } \\
\text { province) } \\
\end{array}$ & 421 & $12 \%>200,2 \%>400$ & {$[15]$} \\
\hline & $\begin{array}{l}\text { Islamic Republic } \\
\text { of Iran }\end{array}$ & 16 & Mean 256, 55\%<100 & {$[18]$} \\
\hline & & 100 & $<30 \%<400$ & {$[18]$} \\
\hline & & 400 & $<15 \%<1400$ & {$[18]$} \\
\hline & Ireland & 1762 & $23 \%>200$, max. 2688 & {$[19]$} \\
\hline & $\begin{array}{l}\text { Italy (3 of } 21 \\
\text { regions) }\end{array}$ & 486 & $\begin{array}{l}\text { Range } 13-1450 \text {, geometric } \\
\text { mean } 78-129,4-17 \%>400\end{array}$ & {$[20]$} \\
\hline & USA & 927 & $\begin{array}{l}2.7 \%>150,0.1 \%>1000 \\
\text { Max. } 2500\end{array}$ & {$[21]$} \\
\hline \multirow[t]{3}{*}{ Kindergartens } & $\begin{array}{l}\text { Italy } \\
\text { regions })\end{array}$ & 1687 & $\begin{array}{l}\text { Range 6-1400, } \\
\text { Geometric mean 38-118, } \\
0.1-15 \%>400\end{array}$ & {$[22]$} \\
\hline & Norway & 3600 & $\begin{array}{l}\text { Range 5-2800, mean } 88, \\
\text { Geometric mean } 44\end{array}$ & {$[22]$} \\
\hline & Slovenia & 730 & $\begin{array}{l}\text { Range } 7-5750, \\
\text { Geometric mean } 58 \\
\text { Range } 10-4700, \\
\text { Geometric mean } 58\end{array}$ & $\begin{array}{l}{[23]} \\
{[24]}\end{array}$ \\
\hline \multirow{5}{*}{$\begin{array}{l}\text { Various work } \\
\text { places }\end{array}$} & Finland & 3050 & Mean 225, 37\%>300 & {$[16]$} \\
\hline & & 993 & Mean $171,12 \%>300$ & {$[16]$} \\
\hline & Germany & & $\begin{array}{l}\sim 60000 \text { workers exposed to } \\
>1000 \mathrm{~Bq} / \mathrm{m}^{3}\end{array}$ & {$[25]$} \\
\hline & $\begin{array}{l}\text { Germany } \\
\text { (Saxony) }\end{array}$ & 36 & $\begin{array}{l}\text { Range } 25-7000 \\
10 \%>1000,20 \%>800\end{array}$ & {$[25]$} \\
\hline & Sweden & 150 & $10 \%>400$ & {$[25]$} \\
\hline
\end{tabular}

\section{International Radon Metrology Programme}

A system of reference, technical support, and regional coordinating laboratories has been established to assist in assuring comparability of radon measurements obtained by different institutions worldwide. It is called the International Radon Metrology Programme (IRMP). The programme is being co-ordinated by the IAEA and the Commission of the European Communities, with the University of Salzburg serving as the scientific secretariat. The laboratories assume the following responsibilities:

- Reference laboratories provide guidance on the scientific issues concerning the metrology of radon (radon-222), thoron (radon-220,) and their decay products, in particular in the areas of laboratory and field 
calibration of measurement devices, field sampling, and survey methods and analytical procedures. Such laboratories have been designated for three regions: Europe, North America, Asia and the Pacific

- Technical support laboratories provide technical support in the form of calibrated exposure chambers, which are used to conduct intercomparison exercises for radon-222, thoron, and their decay products under defined laboratory conditions. Three technical support laboratories have been designated for the IRMP. These are two US Environmental Protection Agency offices in Montgomery and Las Vegas, USA, for radon-222; and CANMET in Elliot Lake, Canada, for thoron.

- Regional co-ordinating laboratories will provide logistical assistance in the co-ordination and conduct of regional activities related to quality assurance programmes concerning radon-222, thoron, and their decay products. These laboratories, which have been designated for four specific regions, are the Institute of Radiation Protection in Brazil for South America; the Australian Radiation Laboratory for Asia and the Pacific; the Atomic Energy Commission of Ghana for Africa; the Institute of Epidemiology in the Czech Republic for Europe and the Middle East; and the Institute of Uranium Mining in Hengyang, China, for Asia. [26]

\section{Selected Major Indoor Radon Studies}

Nationwide surveys have been undertaken by Europe and North America and many East European countries to determine radon levels in homes and to assess consequent risks of lung cancer. Many countries in temperate zones, including China and Japan, have put into place large programmes on radon in dwellings and in workplaces. Among tropical countries, significant interest has been noted and radon survey programmes on varying scales have been undertaken. The high level of interest in radon further can be noted from the scientific literature. At the International Symposium on the Natural Radiation Environment (NRE IV) held in Lisbon, Portugal, in 1987, 65\% of the 110 published papers dealt with radon alone. Similarly, at NRE V held in Salzburg, Austria, in 1991, about 70\% of the 163 papers dealt with radon issues. Moreover, some 55 countries are participating in the IAEA/CEC coordinated research programme on radon. While it is not possible to present survey results from radon studies from so many countries, several are particularly noteworthy. [26, 27]

\section{United States.}

A survey carried out in the late 1980s by the United States Environmental Protection Agency (EPA) and announced by the US Public Health Service has indicated that indoor radon problems in the USA are more serious and widespread than previously suspected. According to the US Public Health Service, an estimated 5000 lung cancers among non-smokers each year are believed to be due entirely to indoor radon exposure; among smokers, indoor radon exposure played a role in 15000 deaths from lung cancer. Some later estimates indicate even higher figures. The statistics indicate that indoor radon's human toll "probably exceeds by 10 times the problem of outdoor air pollution", the US Public Health Service said. EPA's recommendation for a further survey to test more houses was supported by the US Surgeon General, the American Medical Association, the American Lung Association, and other health organizations. A national residential radon survey programme carried out by EPA from 1989 to 1991 estimated the frequency distribution of average annual radon concentrations in occupied housing units across 50 states. A 22-page questionnaire collected information on various factors. The results indicated that the arithmetical average annual radon concentration was 46 plus or minus 2 Becquerels per $\mathrm{m}^{3}$. It also indicated that about 6 million housing units exceeded the action level of 150 Becquerels per $\mathrm{m}^{3 .}[25]$.

\section{United Kingdom.}

An estimate made by the National Radiological Protection Board (NRPB) in 1989 on the incidence of lung cancer from indoor radon exposure in the United Kingdom suggested that "radon may be responsible for anything up to 2500 or more lung cancers in a year out of the total of 4100". Indoor radon accounts for half of the average exposure of the UK population to ionizing radiation. Up to the summer of 1991, measurements of radon in 58000 homes were carried out in anticipation of follow-on epidemiological studies, plus implementation of remedial and preventive measures. Radon concentrations above the action level of 200 Becquerels per $\mathrm{m}^{3}$ have been discovered in so far in about $10 \%$ of homes. Despite this successful start, about $90 \%$ of potentially affected homes remain to be identified. [26, 27]

\section{China.}

An epidemiological investigation was started in 1972 in areas having high levels of background radiation near Yangjang, China. A high background radiation area (HBRA) was chosen where natural radiation levels are three times higher than in a nearby control area. About 80000 inhabitants in each area whose families have lived there for two or more generations were studied. The annual averaged effective dose equivalents in the HBRA were $5.4 \mathrm{mSv}$ and $2 \mathrm{mSv}$ in the control area from combined exposure to external gamma radiation and radon and its daughters [26]. Environmental carcinogens and mutagens other than natural radiation, as well as host compounding factors, were studied. The investigation covered 1 million person years of observation to 
investigate cancer mortality in the two areas. Results of the study found no increase of cancer mortality in the HBRA as compared to the control area. On the contrary, there was an observable trend of lower cancer mortality in the HBRA. The incidences of hereditary diseases and congenital defects were similar in both areas. The frequency of chromosomal aberrations in circulating lymphocytes was higher in the HBRA than in the control area. [26]

\section{Islamic Republic of Iran}

The arithmetic means for hotel rooms in Ramsar, , were $90 \mathrm{~Bq} / \mathrm{m}^{3}$ for old hotels and $50 \mathrm{~Bq} / \mathrm{m}^{3}$ for new hotels [26]. Six hospitals surveyed in Madrid, Spain, had values ranging from 10 to $260 \mathrm{~Bq} / \mathrm{m} 3$ with a mean of about $50 \mathrm{~Bq} / \mathrm{m}^{3}$ [27]. Four other public buildings in Madrid had values ranging from 18 to $350 \mathrm{~Bq} / \mathrm{m}^{3}$ with a mean of $88 \mathrm{~Bq} / \mathrm{m}^{3}$.

\section{In Ireland}

Radon levels have been measured in a total of 320 workplaces other than schools. The maximum radon concentration measured was $2900 \mathrm{~Bq} / \mathrm{m}^{3}$ [17]. Because of the diversity of the workplaces surveyed, their wide geographical distribution and the non-random nature of their selection, a calculated mean value is considered to have almost no meaning from a practical perspective.[26, 27]

\section{Finland}

About 7000 radon measurements have been made in above ground workplaces in the areas where the highest radon concentrations had been previously found in dwellings [18]. About 740 work sites have been issued injunctions to begin measures aimed at reducing radon concentrations. In areas where over $25 \%$ of dwelling measurements exceeded $400 \mathrm{~Bq} / \mathrm{m}^{3}$, a total of 3050 workplace measurements yielded a mean concentration of $255 \mathrm{~Bq} / \mathrm{m}^{3}$, with $19 \%$ of the measurements exceeding $300 \mathrm{~Bq} / \mathrm{m}^{3}$. In areas where $10-25 \%$ of measurements in dwellings exceeded $400 \mathrm{~Bq} / \mathrm{m}^{3}$, a total of 993 building measurements yielded a mean concentration of $171 \mathrm{~Bq} / \mathrm{m}^{3}$, with $12 \%$ of the measurements exceeding $300 \mathrm{~Bq} / \mathrm{m}^{3}$.

\section{Germany}

It is estimated that there are 60000 people in buildings with radon concentrations exceeding 1000 $\mathrm{Bq} / \mathrm{m}^{3}$ [6]. An estimated 2300 people in the water supply and distribution industry in Germany are exposed to radon concentrations above $1000 \mathrm{~Bq} / \mathrm{m}^{3}$ in the office building. In a recent small study of 36 workplaces in Saxony, indoor radon levels were found to range from 25 to $7000 \mathrm{~Bq} / \mathrm{m}^{3}$, with $90 \%<1000 \mathrm{~Bq} / \mathrm{m}^{3}$ and $80 \%<$ $500 \mathrm{~Bq} / \mathrm{m}^{3}[19]$.

\section{Greece}

Recent monitoring of radon in a limited number of types of sites has commenced [20]. Apart from underground mines these include radon spas, a coal power plant and the Athens metro (underground railway), which is currently under construction. In the radon spas the equivalent equilibrium concentration of radon ranged from 50 to $18000 \mathrm{~Bq} / \mathrm{m}^{3}$ while in two main metro stations radon concentrations were quite low, ranging from about 9 to $22 \mathrm{~Bq} / \mathrm{m}^{3}$. At the coal power plant investigated, radon concentrations were found to range from 15 to $181 \mathrm{~Bq} / \mathrm{m}^{3}$ [21]..

\section{Italy}

In some workplaces, research surveys have shown very high concentrations, for example in thermal baths (up to several thousands of $\mathrm{Bq} / \mathrm{m}^{3}$ ). Other workplaces in Italy such as geothermal plants are also expected to give rise to radiation protection concerns due to high radon levels. Radon concentrations of several thousands of $\mathrm{Bq} / \mathrm{m}^{3}$ have been measured in the catacombs of Rome, which are workplaces for guides. [26, 27]

\section{Canada}

New Health Canada research indicates there are hundreds more cases annually of lung cancer caused by indoor radon exposure than first determined in the late 1970s, prompting the agency to urge Canadians to check radon levels of in their homes [27]

Health Canada tests conducted in the late 1970s estimated that 10 per cent of lung cancers resulted from indoor radon gas. However, the federal agency more accurately determined the levels of radon through tests of 14,000 homes across the country for two years starting in 2007. The testing, using long-term alpha track detectors, determined that more Canadians are exposed to radon concentrations above acceptable levels than previously recorded. As a result, the new estimate of lung cancers attributable to radon exposure is now 16 per 
cent. Roughly the same number of homes were tested in both undertakings. But the most recent testing is much more accurate than the 1970s "grab-sample testing," the only method available at the time. Based on Health Canada's latest testing, indoor exposure to the gas can be expected to cause more than 3,000 lung cancer deaths each year. If all homes with dangerous radon levels were "remediated to the outdoor level," 927 of the anticipated 3,261 radon-induced lung cancers could potentially be prevented per year.

The two-year testing also found seven per cent of the 14,000 homes had levels of radon above the acceptable level of 200 Becquerels per cubic metre of air $\left(\mathrm{Bq} / \mathrm{m}^{3}\right)$, up from three to five per cent in the 1970s testing.

\section{Practices, Interventions And Action Levels}

One basic concept of radiation protection is to divide activities into practices and interventions. A 'practice' is "Any human activity that introduces additional sources of exposure or exposure pathways or extends exposure to additional people or modifies the network of exposure pathways from existing sources, so as to increase the exposure or the likelihood of exposure of people or the number of people exposed. An 'intervention' is "Any action intended to reduce or avert exposure or the likelihood of exposure to sources which are not part of a controlled practice or which are out of control as a consequence of an accident.

The use of action levels is helpful to clarify the basis for this distinction. The action level is the radon concentration at which remedial or protective actions will need to be undertaken to reduce excessive exposures to radon in dwellings. Over the years, governments and international bodies have set "action levels" for radon exposures. According to the International Commission on Radiological Protection (ICRP), they are meant for initiating intervention in order to help in deciding when to require or advise remedial action in existing dwellings. The choice of an action level is complex, depending not only on the level of exposure, but also on the likely scale of action, which has economic implications for the community and for individuals. It is thus not to be expected that the same action level will be appropriate in all countries. Action levels that have been adopted appear to differ. Similarly, the upper bound of radon concentrations for future new buildings differs from country to country. The IAEA, in its current revision of the Basic Safety Standards, recommends 200 Becquerels of radon-222 per $\mathrm{m}^{3}$ as the action level for dwellings and 1000 Becquerels per $\mathrm{m}^{3}$ for workplaces.[28]

\section{Conclusion}

The processes of radon production and transport in the environment indicated that radon can be found in all homes worldwide, particularly in areas having soil and rocks that are very rich in uranium. Radon has been conclusively implicated as a carcinogen as a result of alpha radiation associated with its daughter nuclei and the effects of genomic changes caused by interaction of these alpha particles with oxygen radicals present in lung cells. Epidemiological studies of underground miners, which indicated a markedly increased risk of lung cancer also provides additional evidence. The risk of lung cancer is further increased by cigarette smoking since cigarette smoking and exposure to radon are complimentary agents of lung cancer risk. On the basis of these findings, exposure to radon in homes is expected to be a cause of lung cancer risks in the general population. This therefore confers on various governments the responsibility of setting action guideline for radon exposure and putting in place a well articulated environmental radon monitoring initiative aimed at reducing radon exposure levels in the general population.

\section{References}

[1] International Commission on Radiological Protection, Protection against radon-222 at home and at work, Publication 65, Pergamon Press, Oxford (1993).

[2] Wilkening, M.H., Watkins, D.E., Air Exchange and ${ }^{222}$ Rn concentrations in the Carlsbad caverns, Health Phys. 31 (1976) $139-145$.

[3] Yarborough, K.A., "Radon and Thoron produced radiation in national park service caves", Natural Radiation Environment iii (Gesell, T.F., Lowder, W.M., eds), Conf-780422, Vol. 2,United States Department of Energy, Washington, DC (1980) 1371-1395.

[4] Kobal, I., Smodiò,B.,Burger,J.,Okofjanec, M., Atmospheric ${ }^{222}$ Rn in tourist caves of Slovenia, Yugoslavia, Health Phys. 52 (1987) 473-479.

[5] Prichard, H.M., Gesell, T.F., ${ }^{222}$ Rn in municipal water supplies in the Central United States, Health Phys. 45 (1983) $991-993$.

[6] Commission on Radiological Protection, Statement of The Commission on Radiological Protection (SSK) of the Federal ministry for the environment on radiation exposure at working places by natural radionuclides, ssk-heft 10/97, Gustav Fischer-Verlag, Stuttgart (1997). 51

[7] Steinhäusler, F., Long-term measurements of ${ }^{222} \mathrm{Rn},{ }^{220} \mathrm{Rn},{ }^{214} \mathrm{~Pb}$ and ${ }^{212} \mathrm{~Pb}$ concentrations in the air of private and public buildings and their dependence on meteorological parameters, Health phys. 29 (1975) 705-713.

[8] Turk, B.H., Indoor air quality and ventilation measurements in 38 Pacific northwest commercial buildings, Rep. lbl-21453, Lawrence Berkeley laboratory, Berkeley, Ca (1986).

[9] Cohen, B.L., Kulwicki, D.R.,Warner, K.R., Grassi, C.L., Radon concentrations inside public and commercial buildings in the pittsburgh area, Health phys. 47 (1984) 399-405.

[10] United States Environmental Protection Agency, Radon in Federal buildings: a report to congress on the results of Federal agency radon surveys, EPA, Washington, DC (1992). 
[11] UNC geotech, results of the us department of energy indoor radon study, rep. doe/id/12584-75 vol. 1 (cng/gj-tp-1), US Department of energy grand junction projects office, grand junction, co (1990).

[12] Scott, H.L., Initial studies on levels of indoor radon at us department of energy facilities, Health phys. 62 (1992) s59.

[13] Dixon, D.W., National radiological protection board, united kingdom, personal communications, 1995, 1999.

[14] Poffijn,A., Uyttenhove, J., Drouget, B., Tondeur, F., The radon problem in schools and public buildings in Belgium, Radiat. prot. dosim. 45 (1992) 499-501.

[15] Sohrabi, M., Zainali, H., Mahdi, S., Solamanian, A.R., Salehi, M., "Determination of the ${ }^{222}$ Rn levels in houses, schools and hotels of Ramsar by Atomic energy organization of Iran with passive radon diffusion dosimeters", high levels of natural radiation (Proc. int. conf. Ramsar, Islamic republic of Iran, 1990), IAEA, Vienna (1993).

[16] Castro, J., "Results from the study of radon inside sanitary centers, public buildings and dwellings in the Madrid area", Proc. 4th natl. congress of the Spanish radiation protection society, vol. ii, Ciemat, Madrid (1991) 283-295.

[17] Mcgarry, A., Radiological Protection Institute of Ireland, Personal communication, 1999.

[18] Radiation and Nuclear Safety Authority of Finland, "Report on radon in aboveground workplaces", Radiation protection at workplaces with increased levels of natural radiation exposure (Proc. int. workshop Salzgitter, 1998), Bundesamt für Strahlenschutz, Berlin (1998).

[19] Bundesamt für Strahlenschutz, Berlin, Personal communication, 1999.

[20] Dimitriou, P., Koukouliou, V., Karinou, E., Hadjiantoniou, A., "Report of Greek Atomic energy commission", Radiation protection at workplaces with increased levels of natural radiation exposure (Proc. int. workshop Salzgitter, 1998), Bundesamt für Strahlenschutz, Berlin (1998).

[21] Agenzia Nazionale per la Protezione Dell'ambiente, "Report on natural radiation exposures in Italy", Ibid.

[22] Swedish Radiation Protection Institute, "Status report on radon in workplaces", Ibid.

[23] Vaupotič, J., Indoor radon concentrations in kindergartens from different regions of Yugoslavia, Radiat. prot. dosim. 45 (1992) 487-493.

[24] Vaupotič, J., Szymula, M., Solecki, J., Chibowski, S., Kobal, I., Preliminary indoor radon investigations in lublin region, poland, health phys. 64 (1993) 420-422.

[25] Vaupotič, J. Systematic Indoor radon and gamma measurements in kindergartens and playschools in Slovenia, Health phys. 66 (1994) 550-556.

[26] IAEA Radiation protection against radon in workplaces other than mines, safety reports series 33 (2003)

[27] Jasimuddin U Ahmed Radon in the human environment: assessing the pictures, topical issues, IAEA bulletin 2(1994)

[28] http://news2.onlinenigeria.com/world/189478 radon linked to more lung cancer deaths than previously thought (2013) 